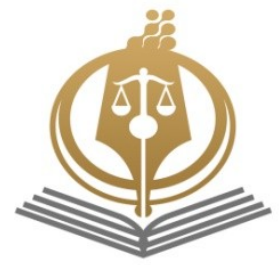

Interdisciplinary Legal Research

Apr 2020, 1(1): 55-66

Available online on: www. ilrjournal.ir

e-ISSN: 2717-1795

ORIGINAL RESEARCH PAPER

\title{
The Right of Happiness for Children, The Manifestation of Human Rights in Modern Times
}

Mehri Toutounchian ${ }^{1}$ *

Received:

21 Mar 2020

Revised:

28 Mar 2020

Accepted:

30 Mar 2020

Available Online:

01 Apr 2020
Keywords:

Right of Happiness,

Children Rights,

Child Friendly,

Human Rights.
Background and Aim: Human rights as a universal approach have various dimensions which are defined as children's rights and including the right to happiness. This approach, particularly with the advent of universal declaration and convention on protecting children's rights has become more common. The main purpose of this study is to look at the right to happiness of children as one of the important manifestations of human rights in contemporary era. Accordingly, the main question of this research is what are the most important strategies for realization of the right to happiness of children?

Materials and Methods: According to the aim of the present study, the descriptive - analytical approach has been chosen as the method of the present study which has collected the relevant information by the documentary and library method.

Ethical Considerations: In order to organize this research, while observing the authenticity of the texts, honesty and confidentiality have been observed.

Findings: Paying attention to the characteristics and behaviors of children friendly nature, providing conditions for children's social participation, creating conditions to form children Friendly City is one of the strategies that can pave the way for children to achieve happiness. Meanwhile, reducing the role of men in building urban spaces and paying attention to emotional and emotional characteristics of children in designing social, educational and urban environment can be considered as a kind of support for children's happiness based on universal human rights approaches.

Conclusion: The realization of the right to child happiness needs to change the attitudes of social and urban life in favor of children 's rights .

\footnotetext{
$1_{*}$ PhD in Jurisprudence and Law, Researcher in The Center of Ethics and Medical Law, Shahid Beheshti University of Medical Science, Tehran, Iran.

Email: Mehri.Toutounchian@gmail.com Phone:+982633408394
}

Please Cite This Article As: Toutounchian, M (2020). "The Right of Happiness for Children, the Manifestation of Human Rights in Modern Times”. Interdisciplinary Legal Research, 1 (1): 55-66. 
مقاله هروهشى

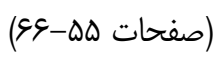

\title{
حق بر شادى كودكان، جلوهاى از حقوق بشر در عصر مدرن
}

\author{
مهرى توتونجيان' \\ ا. دكترى فقه و حقوق، يزوهشكر مركز اخلاق و حقوق يزشكى، دانشحاه علوم يزشكى شهيد بهشتى، تهران، ايران.
}

Email: Mehri.Toutounchian@gmail.com

دريافت: T/1

زمينه و هدف: حقوقبشر بهعنوان يك رويكرد جهانى داراى ابعاد مختلفى است كه بهطور مشخص، حقوق كودكان و از جمله حق بر شادى يكى از

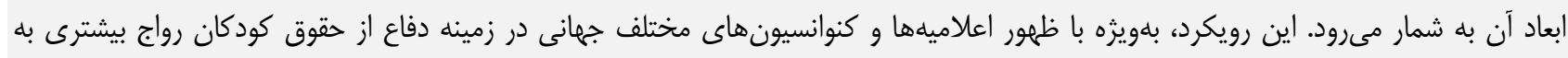

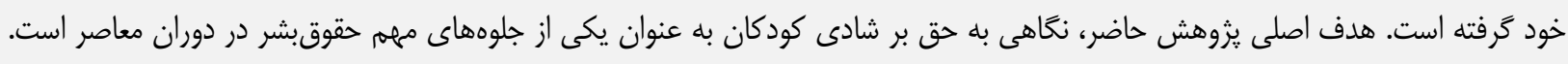

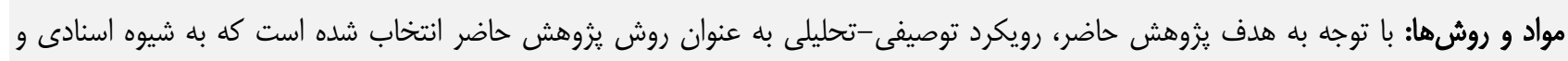
كتابخانهاى، اطلاعات مربوطه را جمع آورى نموده است. ملاحظات اخلاقى: در به سامان رسيدن اين تحقيق ضمن رعايت اصالت متون، صداقت و امانتاندارى رعات رعايت شده است.

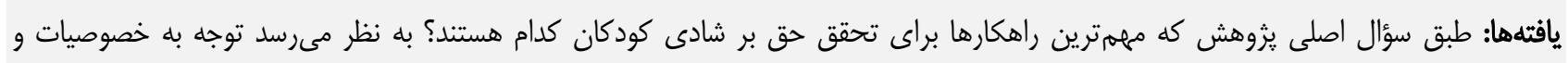

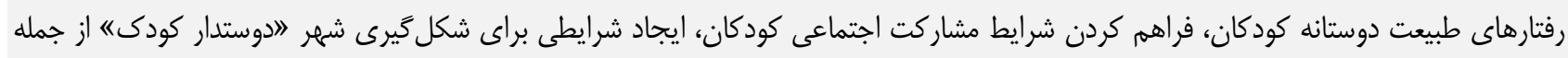

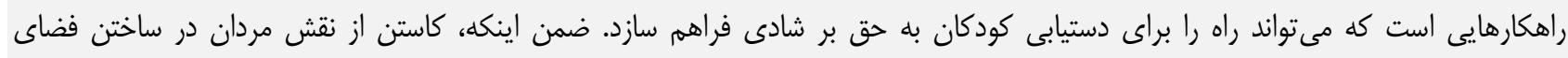

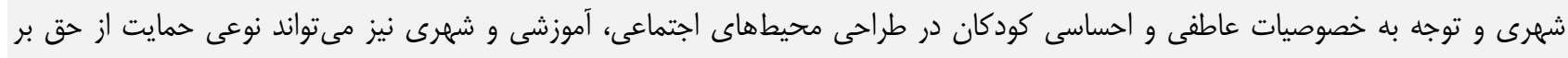
شادى كودكان بر مبناى رويكردهاى حقوق بشر جهانى در اين زمينه تلقى شود.

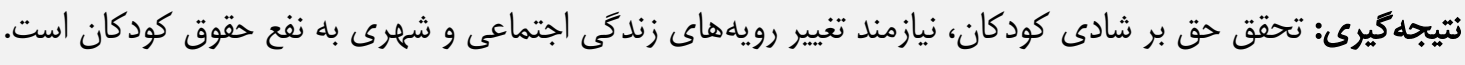
كلمات كليدى: حق بر شادى، حقوق كودكان، دوستدار كودى، حقوق بشر. 
آزادى به كودكان، مصون ماندن آنان از تعرض و محروميتهاى خانوادگى از قبيل: تنبيه بدنى و فيزيكى، آسيبهاى عاطفى، اخلاقى و ... است. همجنين در بُعد اجتماعى لئى نيز اصول اخلاقى و تربيتى نظير آموزش در مدارس، محيطهاى

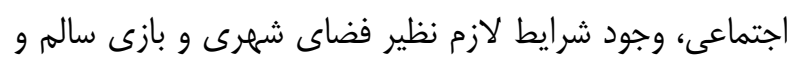

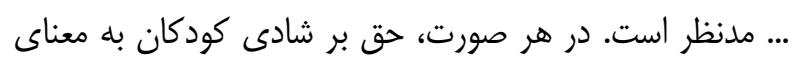
فراهم شدن شرايط مادى و معنوى، فردى و اجتماعى كودكان است كه به راحتى بتوانند حقوق مندرج در آموزههاى حقوق

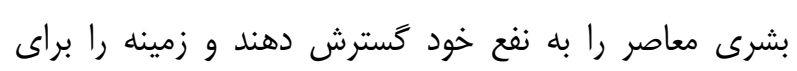
برابرى اجتماعى مهيا سازند. از اين منظر، مجموعه تعاليم حقوق دون بشرى كه در دهdهاى پايانى قرن بيسته ظهور و نمود يافتند، به خوبى حقوق كودكان را در زمينههاى مختلف مورد توجه قرار دادهاند كه رعايت آنان از منظر داخلى، منطقهاى و و بين الملى دمانى خواهد توانست حق بر شادى كودكان را نيز فراهم آورد. علاوه بر اين، نهادهاى آموزشى، اجرايى، تقنينى و حقوقى مى بايست

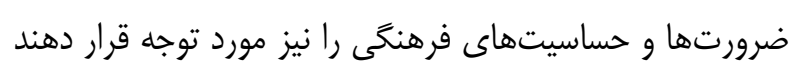
تا كودكان در سراسر جهان و فارغ از نزاد، رنخ يوست، جنسيت، مذهب و طبقه اقتصادى-اجتماعى بتوانند حيات

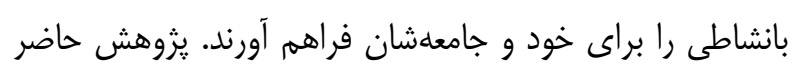

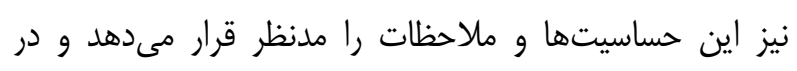
همين راستا تلاش مى كند تا با رويكردى عام و جهان شمهول، اصولى كلى را براى بهبود زندگى مطلوب كودكان مهيا سازد.

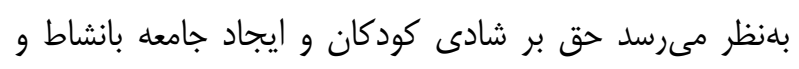

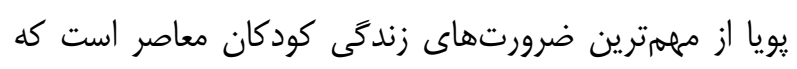

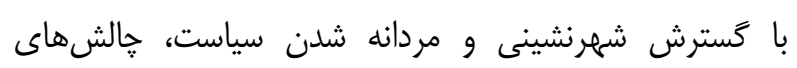
زيادى را براى كودكان ايجاد كرده است. r- تبيين مفاهيم: اولين جلوههاى حقوق بشر كه رويكردى عام و جهانشمول دارد، همزمان با انقلاب فرانسه نمايانگر شده

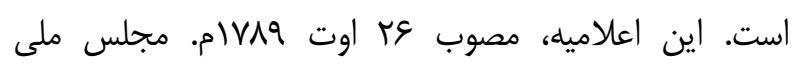
فرانسه است كه در آن، خنين بيان شده است: الافراد آزاد به دين آنيا

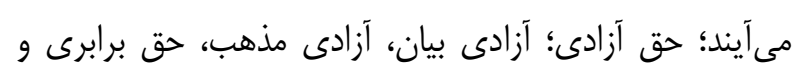

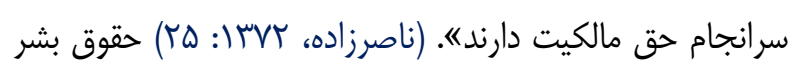
به عنوان مجموعهاى از حقوق انسانها بهكار مىرود كه ابعاد
مقدمه

ا- بيان موضوع: كودكان به عنوان بخش مهمى از جامعه

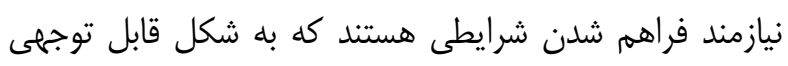

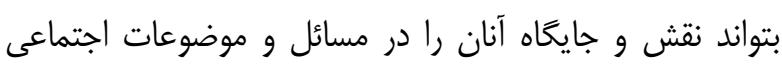

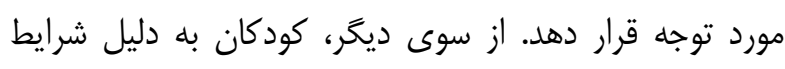
خاصى كه بر زيست اجتماعى آنان حاكم است، نيازمند

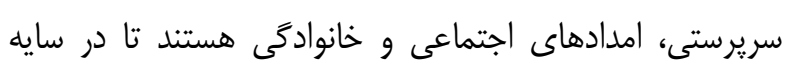

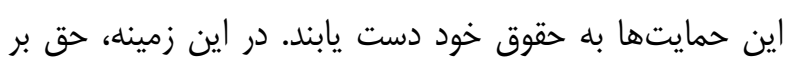
شادى كودكان به عنوان يكى از اصول اساسى زندكى كودكان

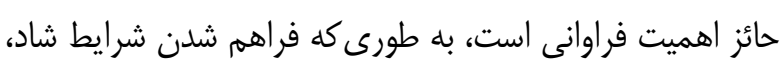

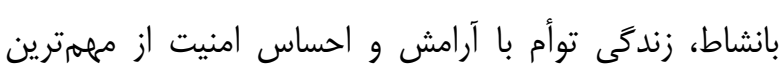

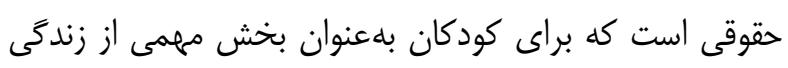

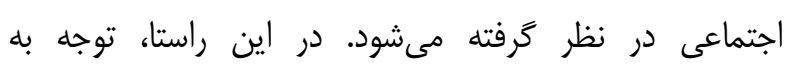

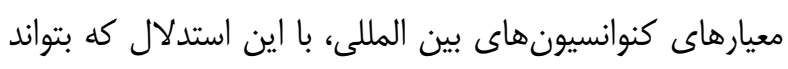

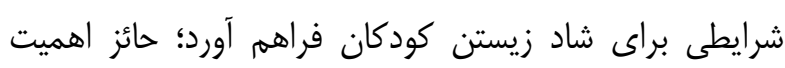

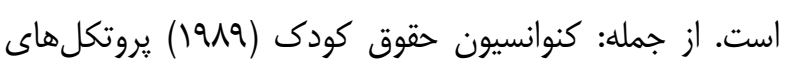

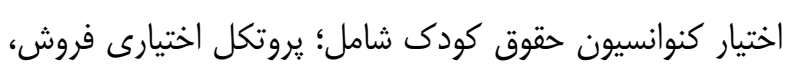
فحشا و هرزهنارى كودكان، يروتكل اختيارى مشاركت

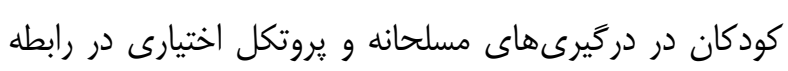

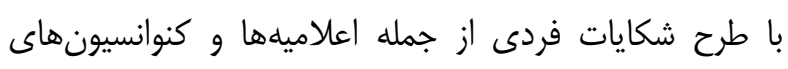
بينالمللى است كه به عنوان حامى حقوق كودكان فعاليت مى كنند. ضرورت انجام يزوهش حاضر، بررسى و ارائه راهكارهايى است

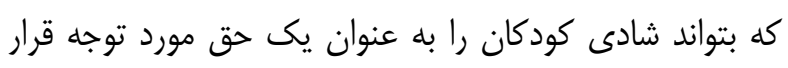
دهد و موانع موجود در اين زمينه را نيز شناسايى كند تا زمينه-

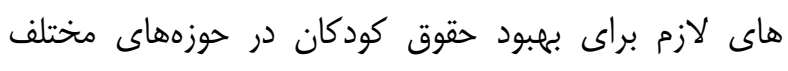

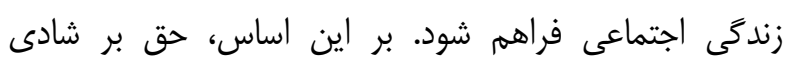

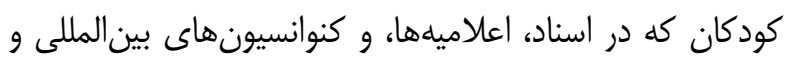
حتى منطقهاى مورد توجه قرار گرفته است، در حوزههاى

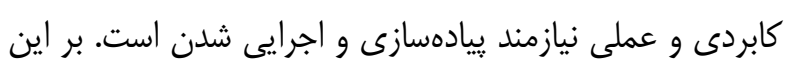

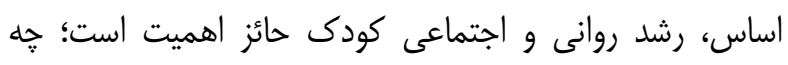
اينكه فراهم ساختن شرايط فردى جهت احقاق حقوق كودكان، نيازمند تربيت صحيح و ساله، آموزش لازم در خانواده، اعطاى 
بشر مىبايست نقش و جايگاه كودكان را نيز مورد توجه ويزه

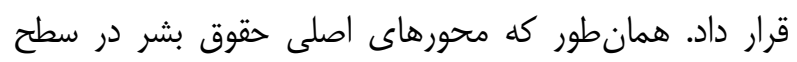
بين المللى، نقش و جايگاه كودكان را نيز مدنظر قرار داده است. در مجموع مىتوان حقوق بشر مطروحه در منابع فوق را فارغ از

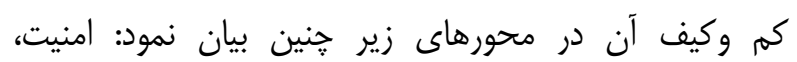

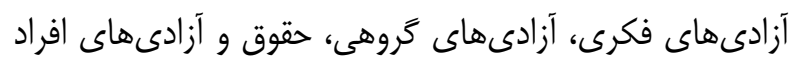

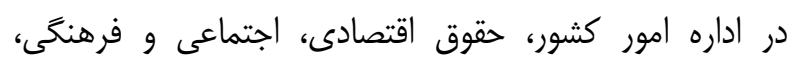
حقوقبشر در موارد خاص (حقوق زنان، حقوق كودى، حقوق

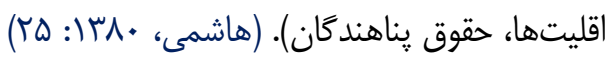
اصول مزبور هريك به نحوى بر حقوق مسلّم و شناختهشده بناه

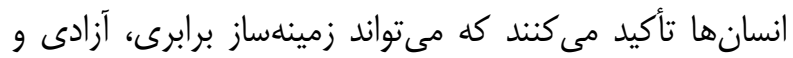
عدالت ميان انسانها باشد. بدينترتيب، شش محور مذكور نيز

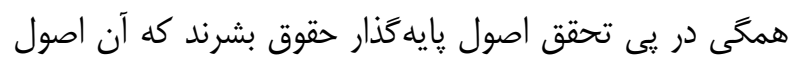

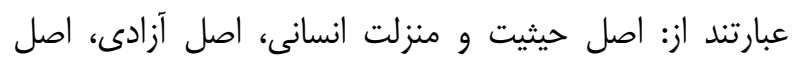

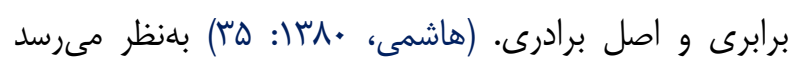

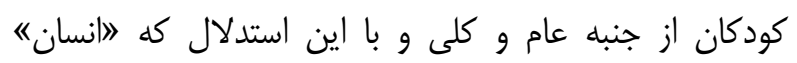
محسوب مى شوند، داراى حقوق خاص خود هستند. همجنين از

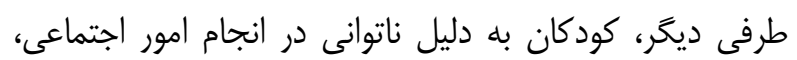
نيازمند حمايت از طرف نهادهاى اجتماعى هستند. ضمن اينكه دستيابى كودكان به حقوق خاص خود، تحت تأثير

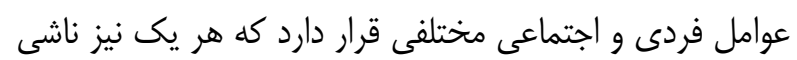
از تجربيات مختلف سياسى و اجتماعى جوامع است. بنابراين در كنار، مؤلفهاى جهانشمولى كه درباره حقوق كودكان وجود دارد، اصول خاصى نيز ديده مىشود كه با توجه به شرايط اجتماعى و سياسى هر جامعه، حقوق متناسبى براى كودكان

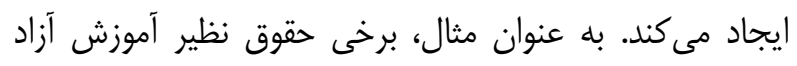

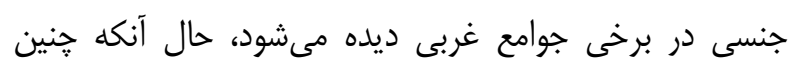
جيزى در حقوق كودكان در جامعه ايرانى ديده نمى شود. با اين وجود، بهرهمندى از يكى محيط خانوادگى سالم، ارتباط

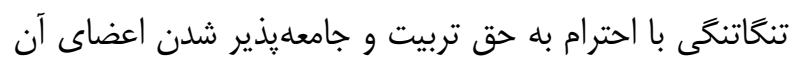

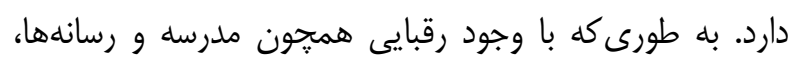
هنوز هم اعتقاد بسيارى بر اين است كه اصول، افكار، ايدهها،

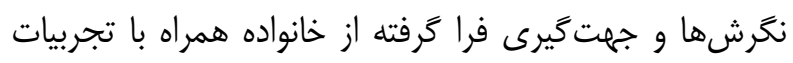

سياسى، اقتصادى، اجتماعى و فرهنكى گَستردهاى نيز به خود

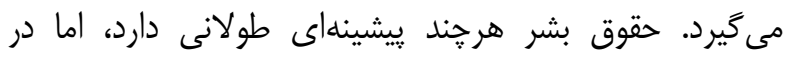

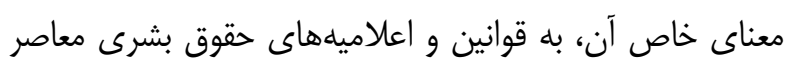

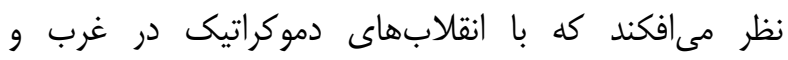

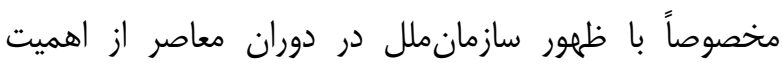
بالايى برخوردار شدند. بلهطور كلى، حقوق بشر در معناى عام

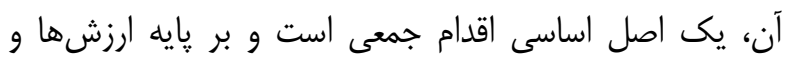

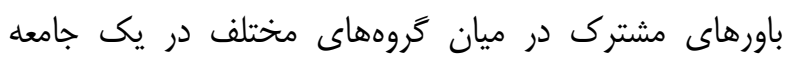
يىريزى شده است. (Himonga \& Stuttaford, 2014:7) شادى و نشاط به معناى برخوردارى انسان از يك زندگى ساله، عارى از نزاع و خشونت، همراه با زيست اجتماعى موردنظر

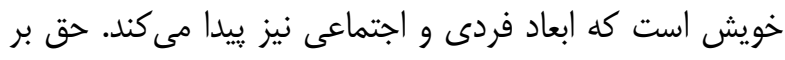

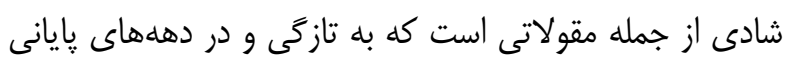
قرن بيستم در اسناد و اعلاميههاى بينالملى مورد توجه قرار كرفت و به قشرهاى مختلف جوامع نيز تسرى يبيدا كرد. در اين

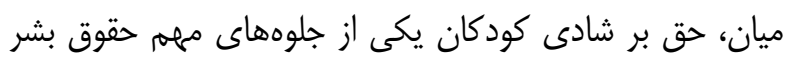

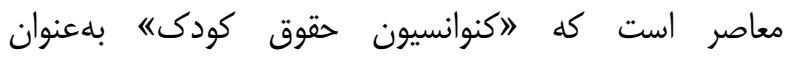
كنوانسيونى جهانى بدان يرداخته است. از سوى ديخر، حق

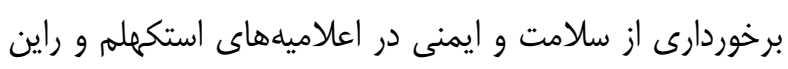
جلوهاى از حق برخوردارى از محيطزيست و حقوق بشر و يافتن ماهيت، تعريف و خارجوب حقوق بشر است. در يرتو اين تركيب، ما مىتوانيم حقوق بشر مربوط به انسان را برشمريه.

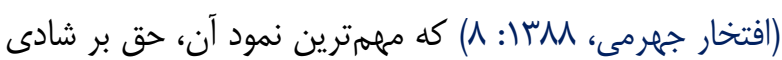
به عنوان يكى از حقوق مسلّم كودكان به شمار مىرود. r- روش تحقيق: روش تحقيق در اين يزوهش بلهصورت تحليلى و توصيفى است.

بحث و نظر

\section{1- إ حقوق كودكان و حقوق بشر}

اخر حقوق بشر به عنوان مفهومى عام و جهان شمول بترول و

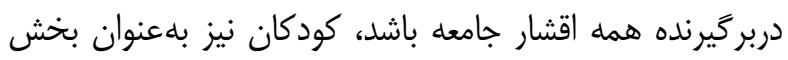
مهمى از جوامع داراى حقوق خاص خود هستند كه البته بهدليل

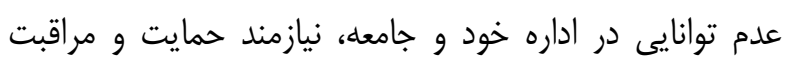
بيشترى مىباشند. بنابراين در بررسى الزامات و قوانين حقوق 
همان طور كه بيان شد، حقوق بشر مفهومى عام و جهانشمول

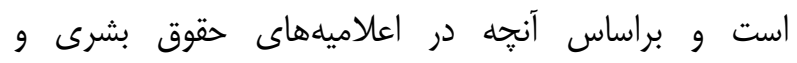
كنوانسيونهاى بينالملى ديده مىشود، كودكان به عنوان بخشى از جامعه كه توانايى קندانى در دستيابى به حقوق خود ندارند، واجد اين حقوق شمرده مئشوند. بنابراين مفاد اعلاميههاى حقوق كودى در نزد نهادهاى بينالمللى، بيش از

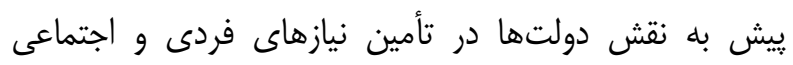

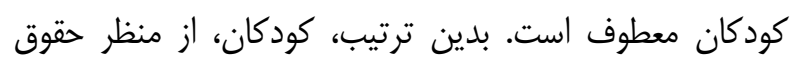
بشرى داراى حقهاى شناخته شده انسانىاند؛ حقهايى كه كه

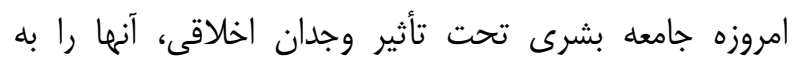

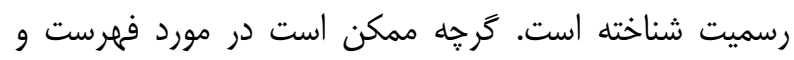
تعداد اين حقها بين ملتها اتفاق نظر وجود نداشته باشد، اما در

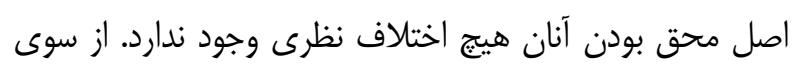

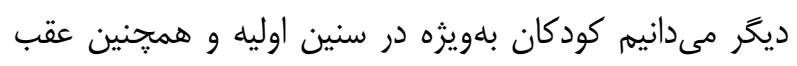

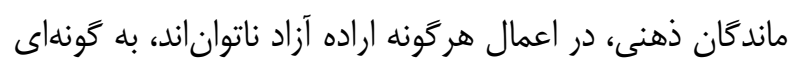
كه اصولا نمىتوان به معناى دقيق در اين گروهها از از اراده

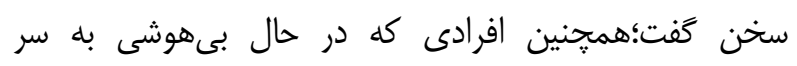

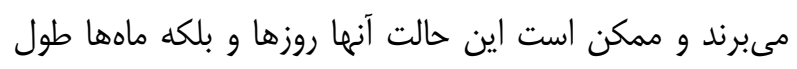

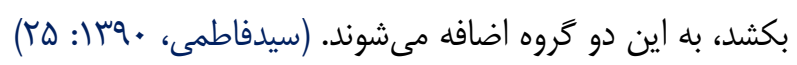
بدين ترتيب، حقوق كودكان در زمره حقوقى شناخته مىشود كه به به

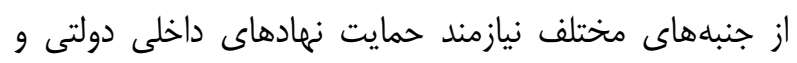
غيردولتى است و از اين جهت، تدوين راهكارها و رويكردها براى احقاق حقوق كودكان در مسأله حق بر شادى، مستلزم توجه به اصلاح رفتارهاى نهادهاى مختلف است. r-1 آموزش شادى و تأمين نيازهاى اوليه كودكان حقوق كودكان و از جمله حق بر شادى كودكان، نيازمند انجام فعاليتهاى مناسب از سوى نهادهاى مختلف از جمله دولت و و جان

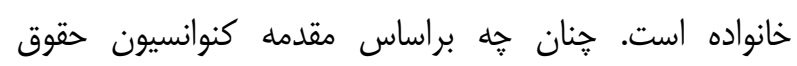
كودى، خانواده به عنوان جز اصلى جامعه و محيط رشد و ورانه رفاه

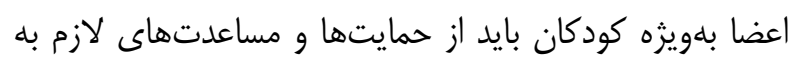

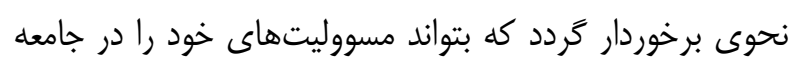

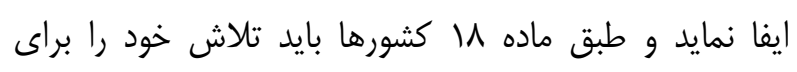

ناشى از شرايط عينى خانواده سبب مى گردد كه هر كودى

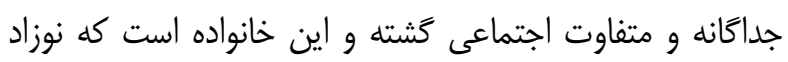
يعنى موجودى بيولوزيكى را به شكل فردى با شخصيت

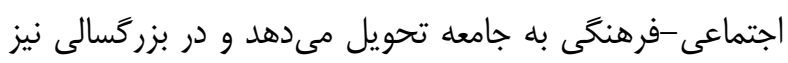

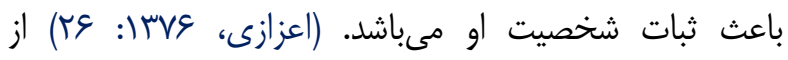
همينرو مىتوان كفت حقوق كودكان در يك جامعه مذهبى باتع تفاوتهاى قابل توجهى با حقوق كودكان در جامعله عرفى و

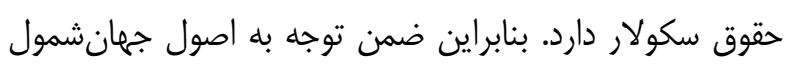
كودكان در زمينه حقوق مختلف از جمله حق بر شادى، مىتوان كونههاى مختلفى از حقوق كودكان را در جوامع مختلف مورد بحث و بررسى قرار داد. علاوه بر اين، مؤلفههاى ديخرى از جمله رسانهها، مسائل

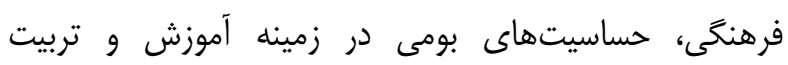
كودكان نيز بر ميزان دستيابى آنان به حقوق انسانى تأثيركذار

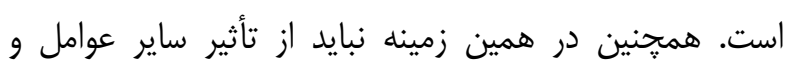

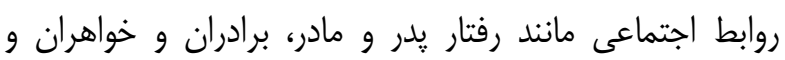

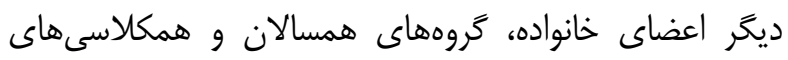

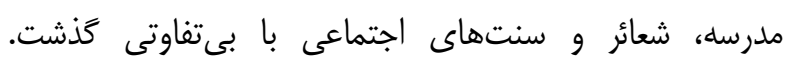

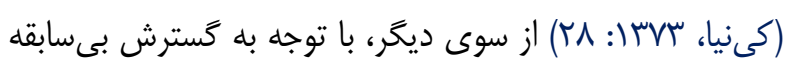

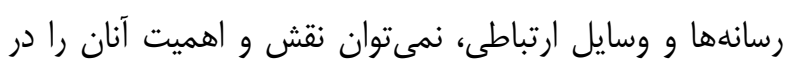
زمينه تأثيركذارى بر حقوق كودكان ناديده گرفت. به به همين

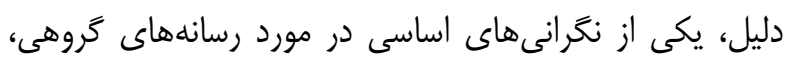

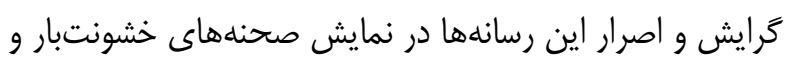
ترويج اين حالات روانى در ميان افراد جامعه به ويزه كودكان و

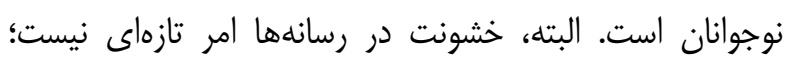

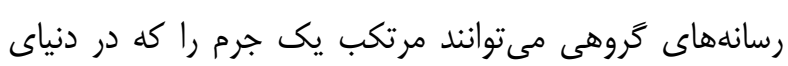

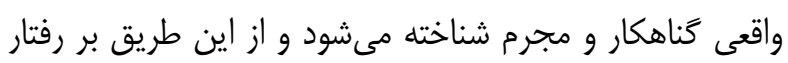

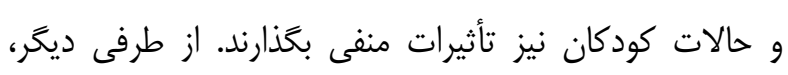
رسانهها مىتوانند ابزار آموزشى مناسبى براى كودكان باشند و از

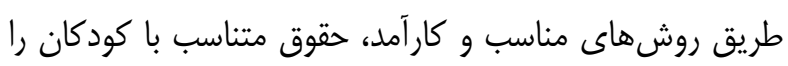
به آنان آموزش دهند. r- حق بر شادى كودكان؛ نيازها و دلايل 
دربركيرنده تمامى حقوق اقتصادى است كه براى يكيارجهسازى

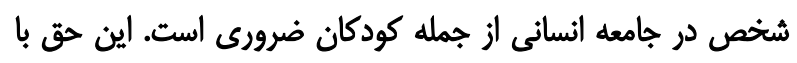

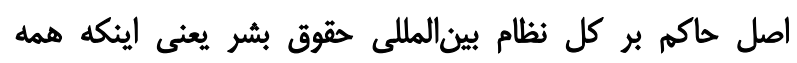

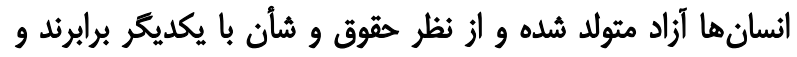
بايد با يكديكر با روحيه برادرى رفتار كنند، رابطه نزديكى داردها

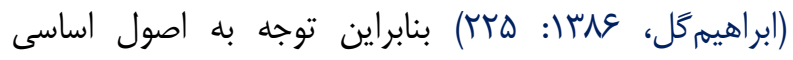

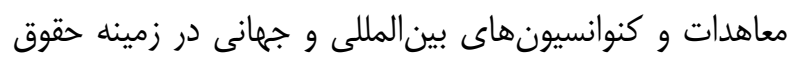
بشر مىتواند جارجوبى براى حقوق كودكان فراهم آورد تا در سايه آن بتوانند حقوق كودكان را مورد توجه قرار دهند. در همين زمينه، ماده بند دوم از ماده ب كنوانسيون حقوق لون

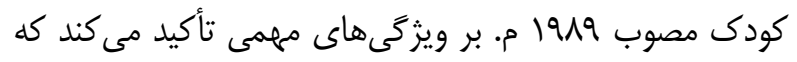

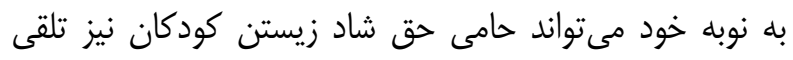

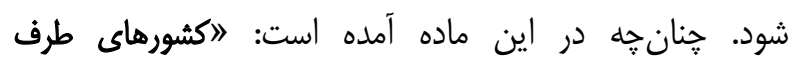
كنوانسيون متقبل مى شوند كه حمايتها و مراقبتهاى لازمه را براى

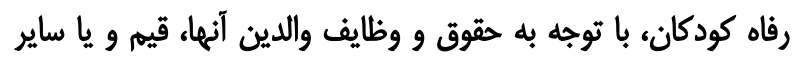

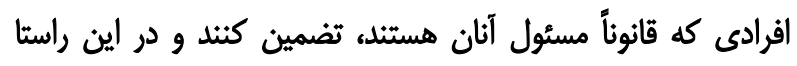

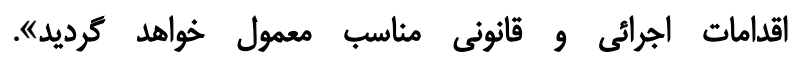
بدينترتيب، فراهم شدن شرايط اقتصادى و اجتماعى مناسب،

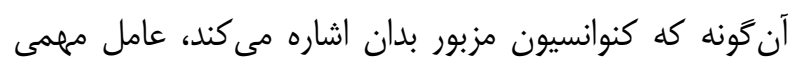
براى بهبود حقوق كودكان در عرصه زندگى شاد مىباشد. از اينمنظر، محيط اقتصادى عمومى، دربرَيرنده نظام اقتصادى حاكم بر جامعه مىباشد كه به نوبه خود مىتواند زمينهساز محيطى سالم براى حقوق كودكان از جمله دستيابى كودكان به

$$
\text { حق بر شادى تلقى شود. }
$$

توضيح اينكه نقش دولتها و تعهد آنان نسبت به آنجه در زمينه مفاد كنوانسيونهاى بينالمللى ديده مىشود، حائز اهميت است. جنانجه، دولتها ضمن برآوردن كليه نيازهاى مادى داخلى، آبادانى جامعه و نظم اقتصادى آن را نيز تأمين نمايند و محيط

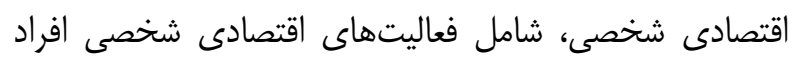

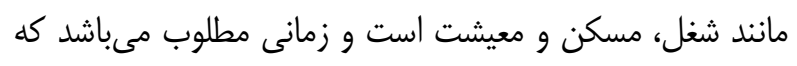
مردم بتوانند از طريق كسب و كار، امكانات معيشتى خود را مانى

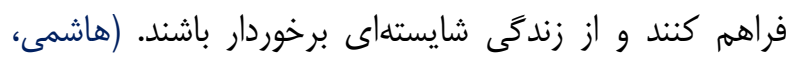

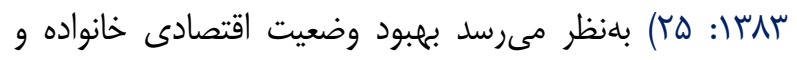
فراهم شدن شرايط براى بهرهمندى كودكان و حتى
تضمين به رسميت شناختن اين اصل كه يدر و مادر كودى مسووليتهاى مشتركى درباره رشد و ييشرفت كودى دارند، به له عمل بياورند. اين موضوع حتى در قوانين داخلى از جمله در

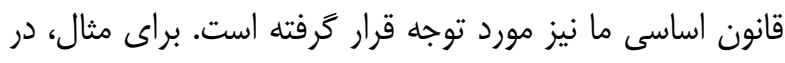
اين باره بند 1 مقدمه قانون اساسى كشور ما خانواده را به عنوان مانه واحد بنيادين جامعه و كانون اصلى رشد و تعالى انسان قلمداد نموده كه زمينهساز اصلى حركت تكاملى و رشد باينده انسان است و فراهم كردن امكانات جهت نيل به اين مقصود را از زماز وظايف اصلى حكومت شمرده است.

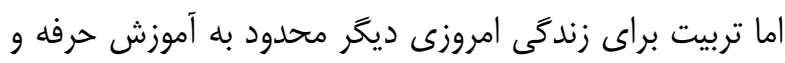

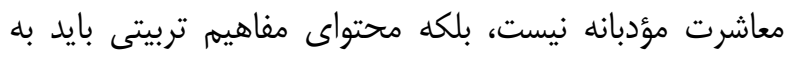

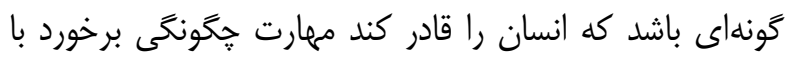

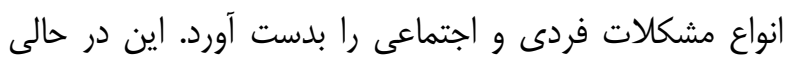

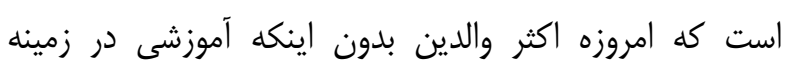
مهارتهاى تربيت فرزند ببيند، يدر و مادر مىشوند. از اينرو، إنها

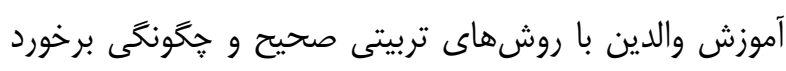
در مراحل مختلف رشد فرزندان يكى از اولويتهاى ضرورى براى استحكام بخشى به محيط خانواده است كه بايد امكانات

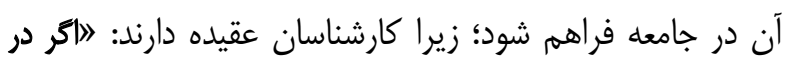
زمان كذشته، يك مادر مىتوانست جند فرزند را به خوبى تربه تربيت

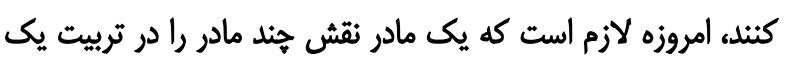

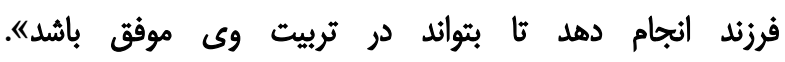

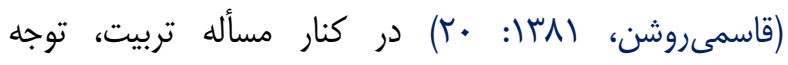
خانوادهها به مسأله شادى كودكان و ايجاد فضايى مفرح براى بازىهاى كودكانه، برقرارى روابط سرشار از شادى و نشاط و ونس همجنين فراهم كردن امكانات تربيتى و اقتصادى براى بهبود روان زندگى كودكان از نيازهاى ضرورى در اين زمينه محسوب مىشوند. بنابراين همانطور كه در ماده 11 ميثاق بين المللى حقوق

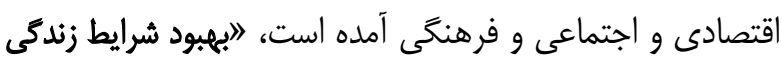

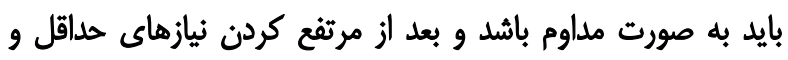

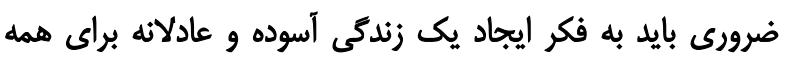

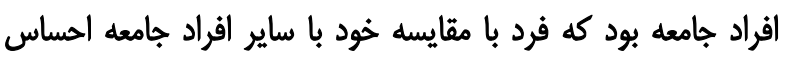
محروميت نكند". از اينرو، "حق بر استاندارد مناسب زندكى 
مسأله ديخرى كه مىتواند جلوهر حق بر شادى كودكان باشد

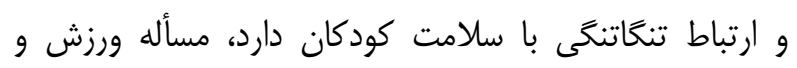
سلامت جسمى كودكان است. به همين دليل بايد كفت طراحى

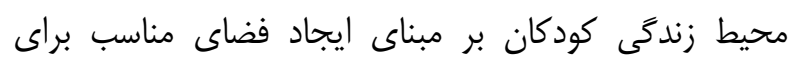
ورزش كودكان نمايانكر توجه به حقوق شادى كودكان است.

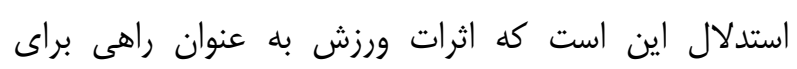
دستيابى به حق بر شادى كودكان اين است كه كسالت و تنبلى إنى

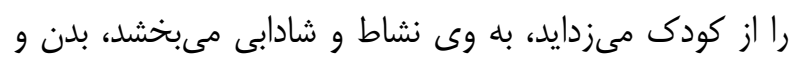

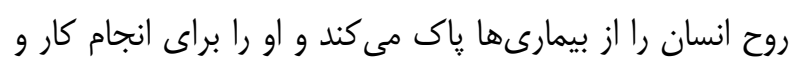
فعاليت و وظايف فردى، اجتماعى، شغلى، دينى و ... آماده

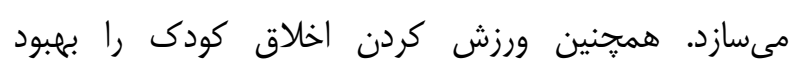

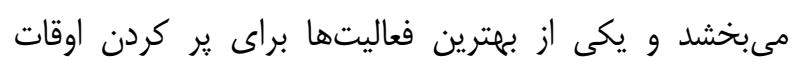
فراغت وى است. از سوى ديخر ورزش روحيه شجاعت، از

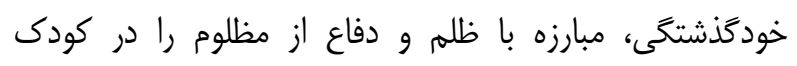

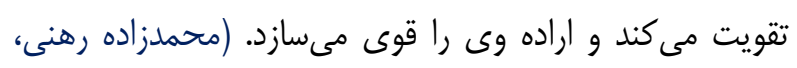

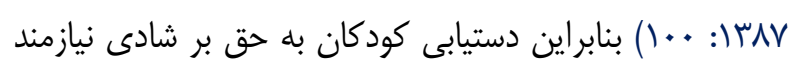

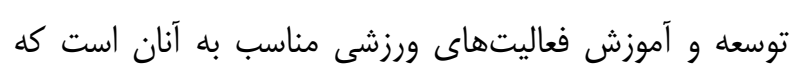

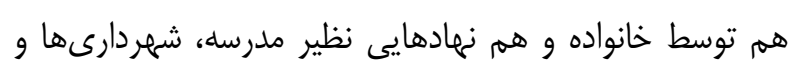

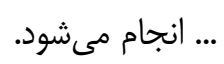

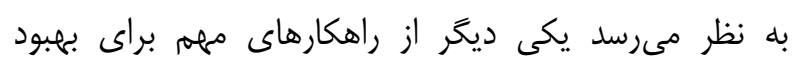
وضعيت شاد در ميان كودكان و دستيابى به حق بر شادى آنان، جلوگيرى از رواج "كودكان كار" در جامعه است كه از معضلات جوامع معاصر اعم از ييشرفته و در حال توسعه به شمار مى روردان

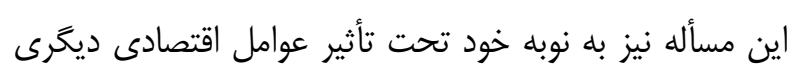

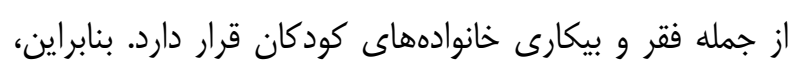

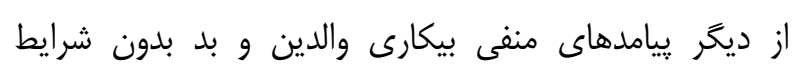

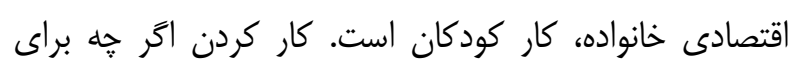
بزرگسالان يك حق است، اما براى كودكان در بسيارى از

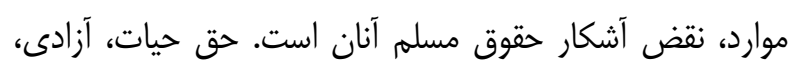

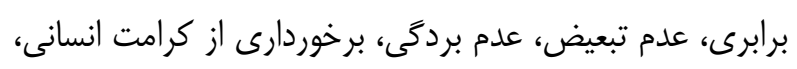

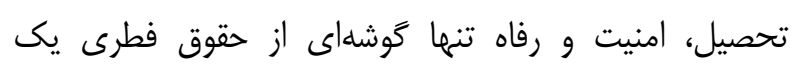

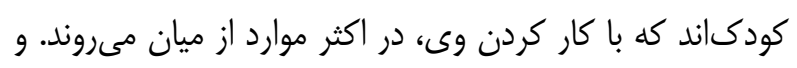

خانوادههاى آنان از شرايط رفاهى مناسب به خوبى مىتواند حامى حق بر شادى كودكان تلقى شود. بنابراين، محيط و

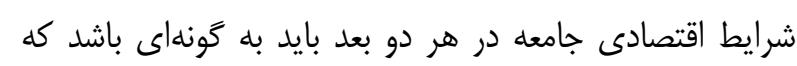

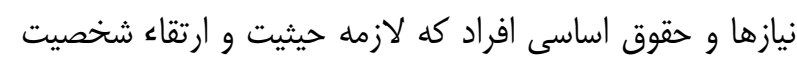
آنها است. به عنوان نمونه، در زمينه خوراك، يوشاك، مسكن، الها

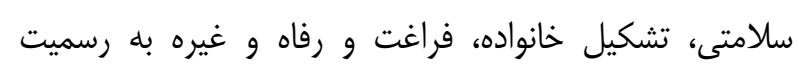
شناخته شود و شرايط مناسبى بلمنظور تأمين اينگونه حقوق

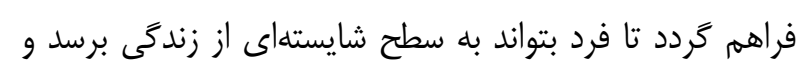
كرامت و شأن انسانى خود را حفظ نمايد. (محمودى نانكى،

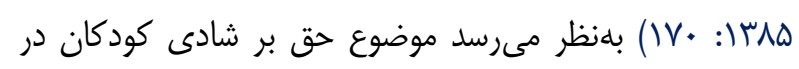

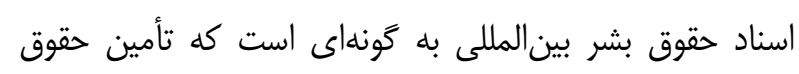

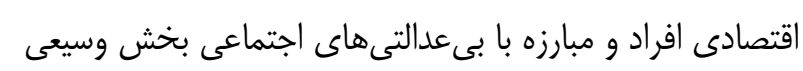

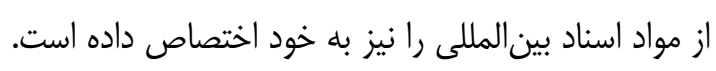

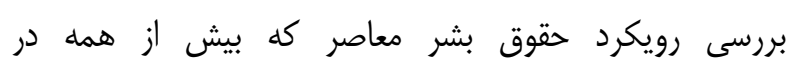

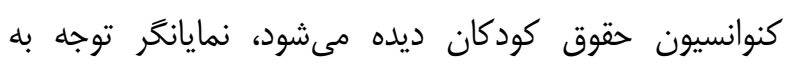
حقوق كودكان از جمله فراهم شدن شرايطى براى انجام دئن

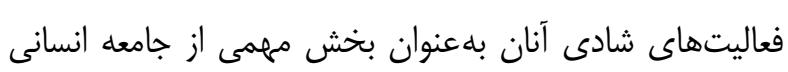

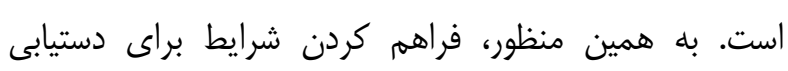

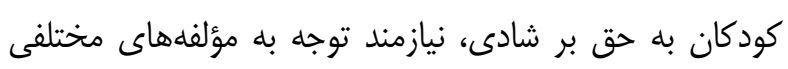

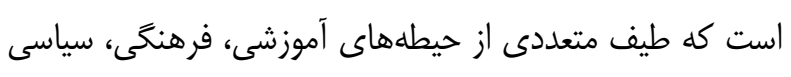
و اجتماعى را در بر مى گيرد. قبل از هر جيز بايد ائ اين نكته بيان شود كه كودكان بلهنوان موجوداتى طبيعت دوست و خواهان

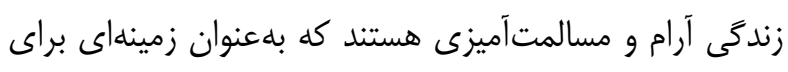
دستيابى به حق بر شادى آنان تلقى مى زشود.

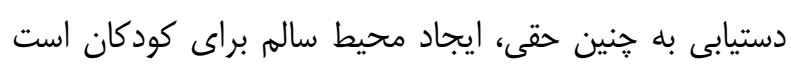

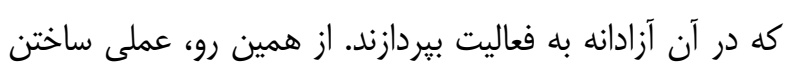
حق سلامت و تحول نظامهاى سلامت يكى از كليدىترين

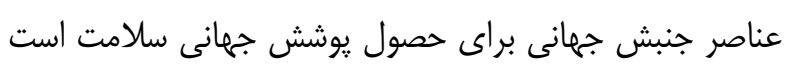

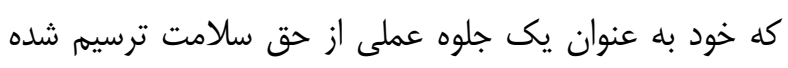

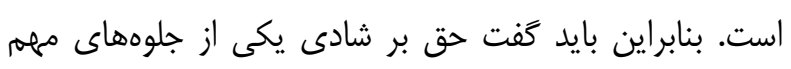

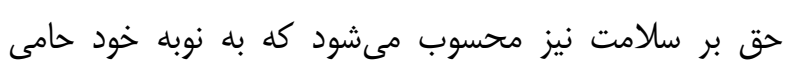
حقوق كودكان است. 
بازى، تفريح، شادى و اوقات فراغت از كارآيى و كيفيت بالايى برخوردار باشد. استدلال اين است كه محيطهاى شلوغ و بسته لهاته شهرى، مانعى براى تحقق حق كودكان بر شادى هستند. از اين منظر، منطقى است كه والدين، جهت تأمين امنيت فرزندانشان، أنها را از اين فضاها دور كرده و مورد محافظت و كنترل

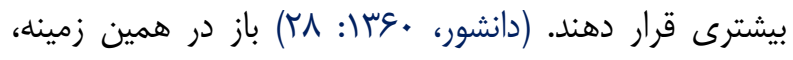
ايجاد "شهر دوستدار كودى" يكى از راهكارهايى است كه مىتواند هم جلوهر حقوق بشر كودكان تلقى شود و هم اينكه باعث توسعه رفتارهاى شادى آفرين در نزد كودكان باشد. از اين منظر كفته مىشود: "ايكى از بهترين روشها براى دستيابى به محيطهاى ساخته شده دوستدار كودى، اين است كه كودكان و

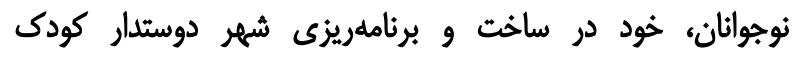

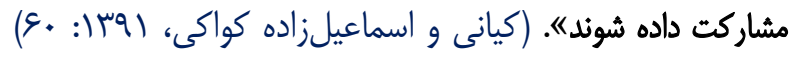
بدينترتيب براى محقق شدن حق بر شادى كودكان، تأمين

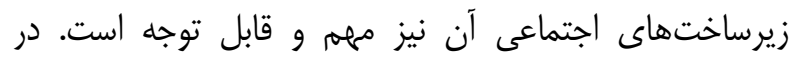

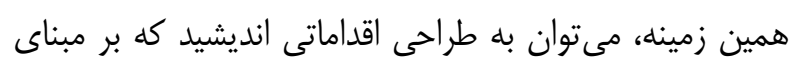
آن، شادى كودكان در محيطهاى طبيعى مورد حمايت قرار كيرد. از اينرو، توجه به فضاهاى سبز و طراحى كردن آنان از

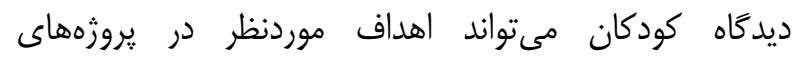
״وستدار كودك" را محقق سازد. (كاملنيا، هوسا: 1ץ) r-r- آموزش حقوق بشر و حق بر شادى كودكان

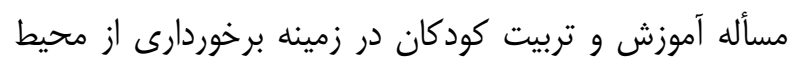

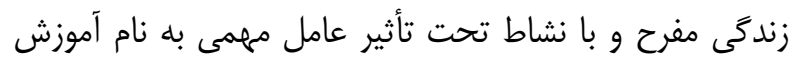

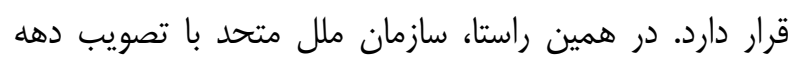

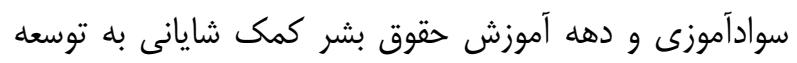

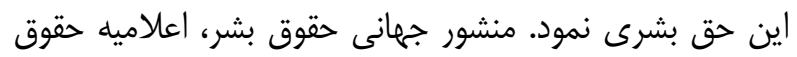

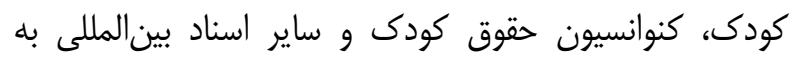
حمايت ويثه از اين حق يرداختهاند. طبق اين اسناد آموزش ابتدايى بايد واجد وصف رايگان و اجبارى براى همه كودكان

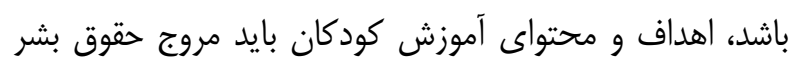
و آزادىهاى اساسى صلح و تفاهم و فارغ از هركونه مبناى تبعيض آميز باشد و كودكان در شرايط دشوار نيز نبايد از اين

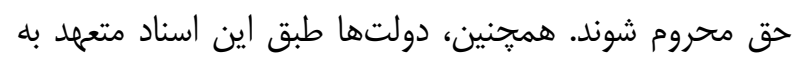

آنها را در معرض خطر انتقام از افراد قرار مىدهد و ضمن آنكه

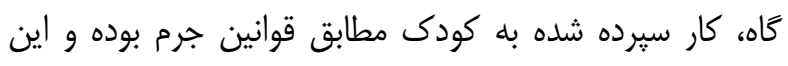
امر ضرورت مبارزه با آن را نمايانتر مىسازد. (غفارى فارسانى، N Y Y ممنوعيت كار كودكان در برخى از مشاغل تأكيد نمودهاند؛ از جمله كنوانسيون "بدترين اشكال كار كودى" مصوب 1999

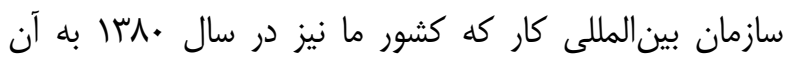

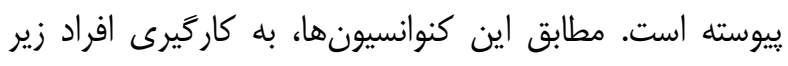

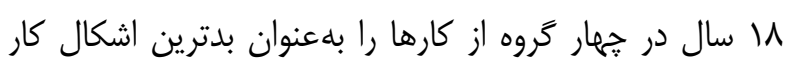
ممنوع اعلام شده است؛ اين جهار دسته عبارتند از: () بردگى و و شيوهها مشابه بردگى همجون رعيتى، قاجاق و فروش كودى، إنى

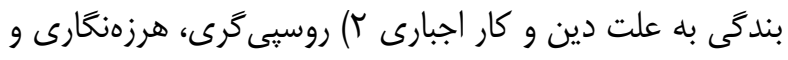

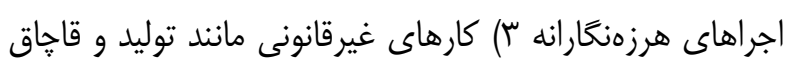

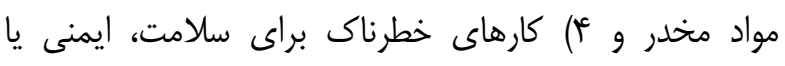

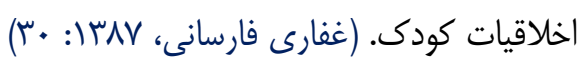
همجنين جهت دستيابى كودكان به حق بر شادى به عنوان يك موضوع يذيرفته شده در اسناد حقوق بشرى معاصر، رويكردهاى مهم ديخرى نيز ديده مى شود. براى مثال، در ماده اس كنوانسيون حقوق كودى و نوجوان (حق بازى و اوقات

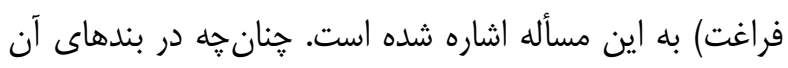

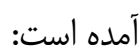

() حكومتها حق كودى را براى داشتن بازى، سركرمى، وقت

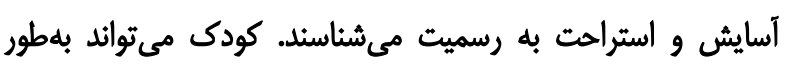

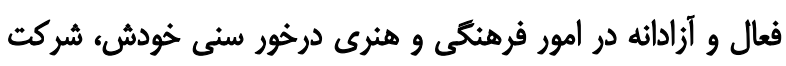
جويد. r آم حكومتها به حق كودى براى فعاليتهاى هنرى و فرهنكى

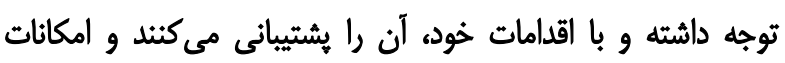
مناسب را براى انجام فعاليتهاى فرهنكى، هنرى و همجنين اوقات فراغت و سركرمى كودى فراهم مىنمايند.

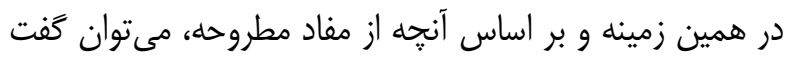
راهكار ديخرى كه در اين زمينه بيان مىشود، توجه به فضاى رئه

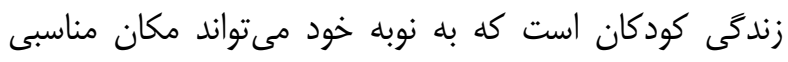
براى ايجاد شادى كودكانه فراهم آورد. بر اين اساس، طراحى مونى شهرى بايد به گَونهاى باشد كه در آن، حقوق كودكان در زمينه 
(آزادى آَاهى) است كه در شرح مواد مربوط به آن خنين آمده

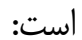

هر كودى حق آزادى بيان دارد و اين حق در بيوند با آزادى

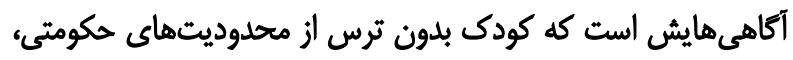

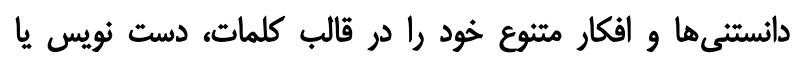
جاب، كارهاى هنرى و يا هر طريق و يا هر وسيله انتخابى ديكر،

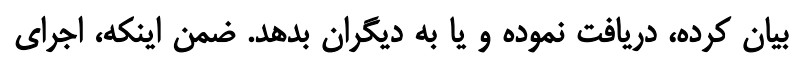
اين حق مى تواند از طرف قوانين ديكرى كه لازم هستند، محدود

شود:

الف) بخاطر حفظ حقوق يا شهرت فردى ديكر؛ ب) بخاطر حفظ امنيت ملى، نظم عمومى، اخلاق و عفت عمومى و

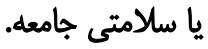
بدينترتيب، كودكان به دنبال ايجاد محيطى مشاركتى هستند كه با هم سن و سالهاى خود در ارتباط باشند. همجنين آنها

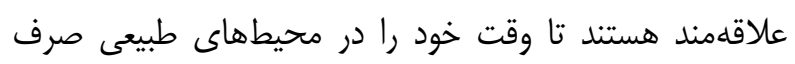
كنند و با ديخران نيز مشاركت داشته باشند. از اينرو، امكانات

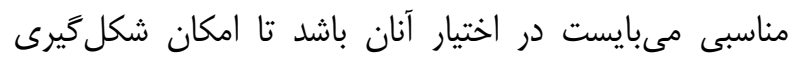
محيطى امن براى آنان فراهم شود. (كيانى و اسماعيلزاده كواكى، (9سا: •(9) ضمن اينكه باز در همين زمينه، بهبود بخشيدن به محيطهاى اجتماعى و شهرى و افزايش نقش كودكان در طراحى محيطهاى بازى، به خوبى مى بهواند

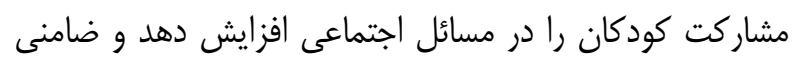
براى حق بر شادى كودكان تلقى شود. براى مثال، ارتقاى فضاى سبز در شهرها موجب يديد آمدن بسترهاى مشاركتى ميان كودكان و ديگر كروههاى سنى در جامعل مى شود.

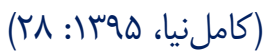
نتيجه كيرى

حقوق بشر جلوههاى گَوناگونى دارد كه توسعه و گسترش آن

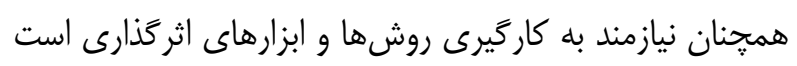

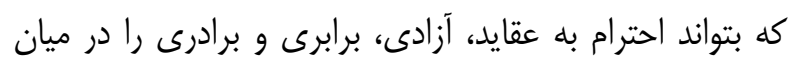

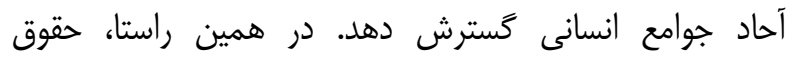
كودكان و از جمله حق بر شادى، از مهمترين تحولات حقوق بشر در دهلهاى يايانى قرن بيستم به شمار مىرود كه از جنبه
احترام، حمايت و استيفاى حق آموزش كودكان هستند. بنابراين به طور كلى بايد شوق زندگى كردن را در كودكان بياموزيه.

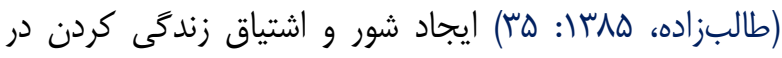
ميان كودكان زمينهساز تحقق حقوق آنان است كه آموزش و

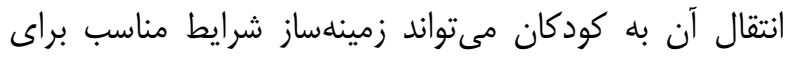

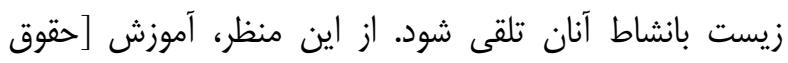
بشر] به كودكان جهت دفاع كودكان از حقوق خود به همه آنان توصيه مىشود تا آنها حداقلهايى از سطح محافظت و حمايت

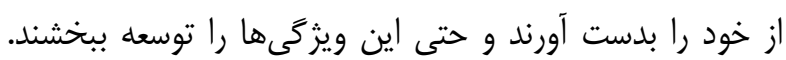

(Lee, 2013:8)

توصيه و دعوت به رعايت حقوقبشر براى كودكان باعث ارتقا و

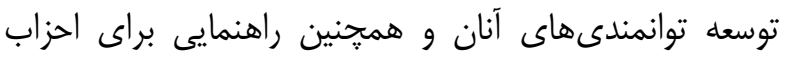

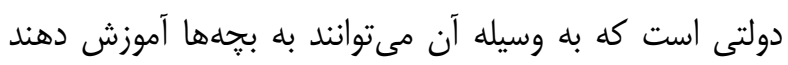
كه از خودشان محافظت كنند، همجنين باعث احترام كذاشتن

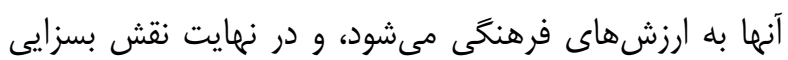
در آشنايى كودكان با حقوق بشر در عرصه روابط بينالملل دارد.

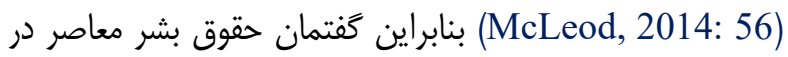
زمينه حقوق شادى كودكان نيازمند توسعه و كسترش همه بله جانبهاى است تا بتواند در ابعاد فردى و اجتماعى، محيط سيط

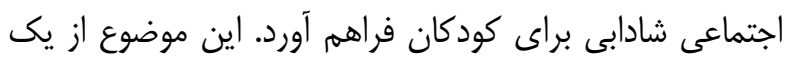
طرف، نيازمند احترام به عقايد كودكان و لزوم دخالت دادن آنان در ساختن محيط زندگى بانشاط است كه امروزه در انواع مهدكودكها، شهربازى و يروزههاى دوستدار كودى دنبط ئبال مىشود. در همين راستا، كنوانسيونهاى حقوق بشر معاصر از

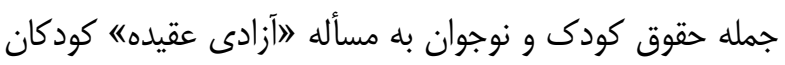
توجه نشان داده است. به طورى كه در ماده ז ז كنوانسيون حقوق كودى و نوجوان (آزادى عقيده) نيز خنين آمده است: (از سوى حكومتهاى امضاءكنده اين بيماننامه، حق كودكى كه توانايى ساختن نظر شخصى خودش را دارد، به رسميت شناخته مىشود. كودى در تمامى امور مربوط به خود، آزادى بيان و اظهار عقيده شخصى را كه مطابق سن و رشد او است، دارد.، از جمله مهمترين مفادى كه در كنوانسيون مربوطه ديده مىشود، مىتواند زمينهساز دفاع از حقوق شادى كودكان باشد، مرك، 
فضا و محيط شهرى به نوبه خود خواهد توانست رويكردهاى

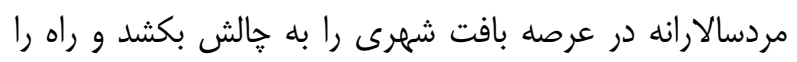

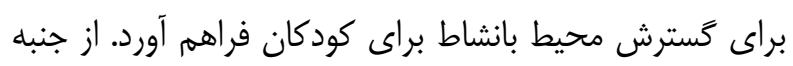

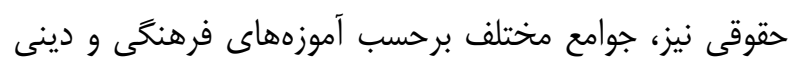
خود و همجنين بازنخرى در قوانين موضوعه خود مى متوانند جايغاه جديدى به حقوق كودكان ببخشند و حق بر شادى

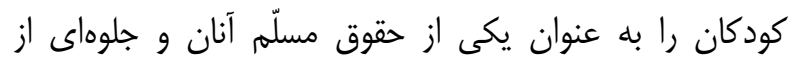
حقوق بشر معاصر مورد توجه قرار دهند.

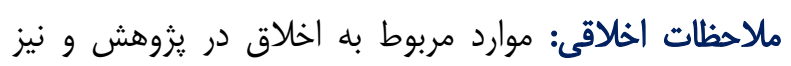
امانتدارى در استناد به متون و ارجاعات مقاله تماماً رعايت كرديد.

تعارض منافع: در تدوين اين مقاله، هيج نوع تعارض منافعى وجود نداشته است.

سهم نويسندكان: تمامى امور اين تحقيق توسط نويسنده طبق

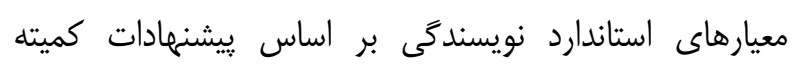
بين المللى ناشران مجلات حقوقى صورت كرفته است. تشكر و قدردانى: در به سامان رساندن اين يزوهش از دوستان و عزيزانى كه با جد بليغ و خضوع، من را يارى نمودهاند، سياسگزارم. تامين اعتبار بروهش: اين يزوهش فاقد تامين كننده مالى بوده
بهبود رفتارهاى فردى، خانوادگى و اجتماعى به حقوق خاص

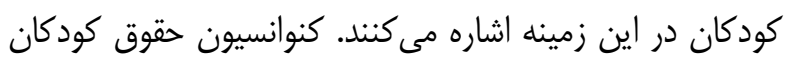
و نهادهاى فراملى ديخرى كه در سطح جهان ديده مى شود بر مئر موضوع "كودكان كار"، ״آزار جنسى كودكان"، " "كودكان بىسريرست و بد سريرست" و همجنين زمينههاى اجتماعى جرمزا توجه نشان دادهاند. از طرفى ديخر و در وجه ايجابى نيز،

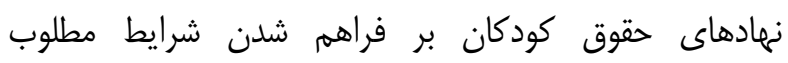
خانوادىى و اجتماعى براى فراهم شدن حق بر شادى كودكان

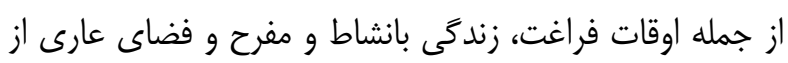

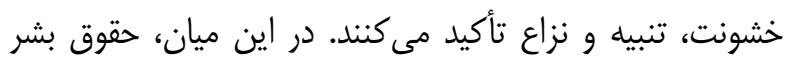
معاصر از جنبه عام و خاص، ضامن حقوق كودكان است؛ از

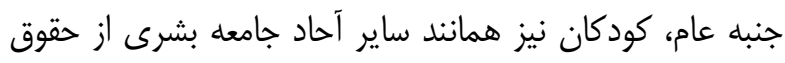

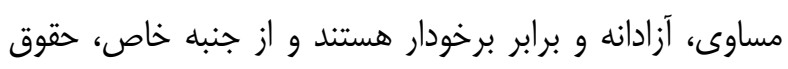
ويزهاى دارند كه در قالب حق بر شادى نيز تجلى ييدا مى كند.

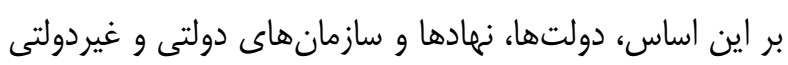
مىبايست شرايط آموزشى، اجتماعى و سياسى مناسبى بركزينتد تا در سايه آن بتوان، حق بر شادى كودكان را تحقق بخشيط.

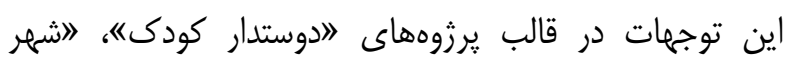
بازى"، اشهر كودكان" و.. تجلى مى يابد. همجنين فراهم

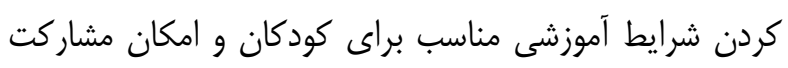

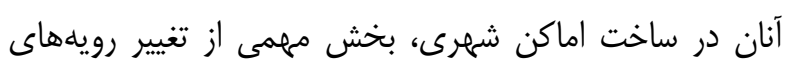
زندگى اجتماعى و شهرى به نفع حقوق كودكان است. تغيير 
- محمدزاده رهنى، محمدرضا (INYV). لابررسى فقهى حوادث

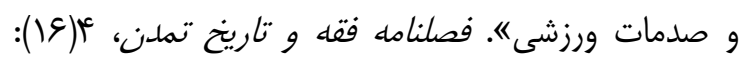
.$|r \Delta-9|$

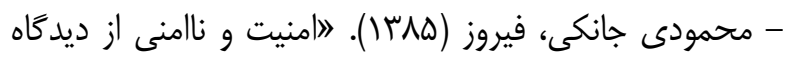
سياست جنايى". فصلنامه ديدأههاى حقوقى، 1(1): $.19 \mathrm{~V}$

- ناصرزاده، هوشنگ (1) (IVY). اعلاميه حقوق بشر. تهران: انتشارات مجد.

- هاشمى، سيدمحمد (•^سار). حقوق اساسى و ساختارهاى سياسى. تهران: انتشارات ميزان.

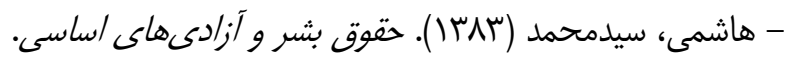
تهران: انتشارات ميزان.

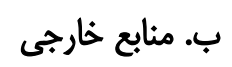

- Himonga, N \& Stuttaford, F.M (2014). "Social Ssolidarity and The Right to Health: Essential Elements for People-Centred Health Systems". Journal Health Policy and Planning, 14(1):18.

- Lee, E (2013). "Education as a Human Rights in the $21^{\text {st }}$ Century". Journal of Democracy \& Education, 27(1): 1-9.

- McLeod, J (2014). A peaceful Pedagogy; Teaching Human Rights Across the Curriculm. Newcastle: The University of Newcastle, Publications Primary Teacher Education.
منابع و مآخذ

الف. منابع فارسى

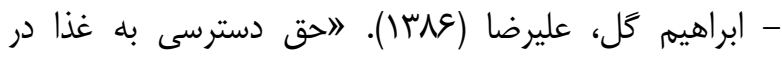

مخاصمات از منظر موازين حقوق بينالملله". فصلنامه

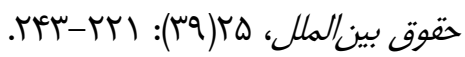

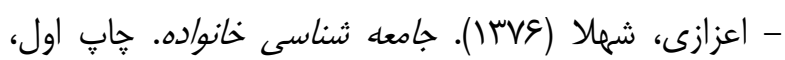
تهران: انتشارات مطالعات زنان.

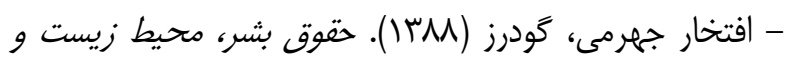

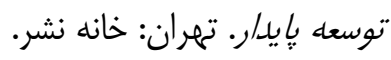

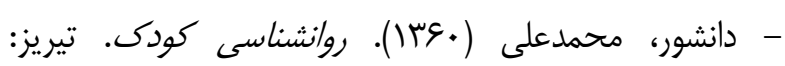
انتشارات دانشعاه تبريز.

- سيدفاطمى، محمدقارى (•وجسا). حقوق بشر در دنياى معاصر.

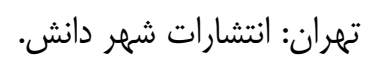

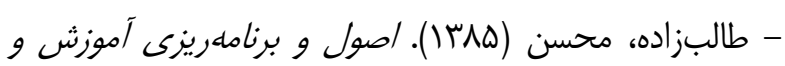
بروش يبش از دبستان. تهران: جهاد دانشخاهى.

- غفارى فارسانى، بهنام (IrAV)

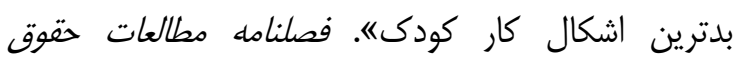

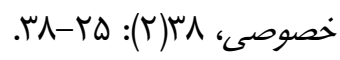

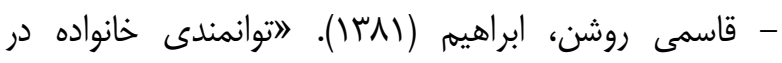

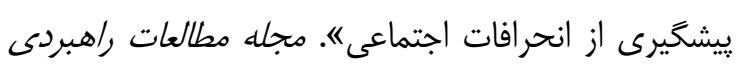

$$
\text { زنان، }
$$

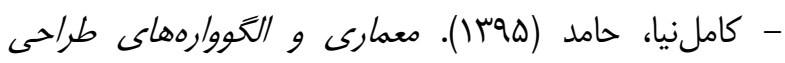

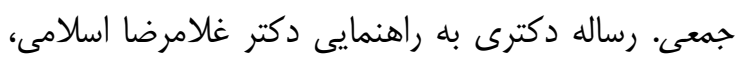
تهران: دانشخاه تهران.

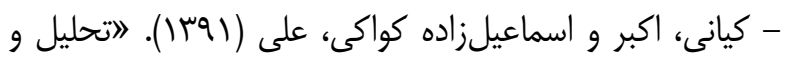

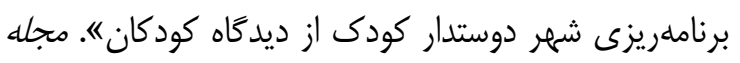

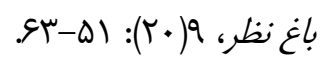

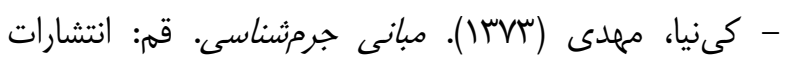
مطبوعات دينى. 


\section{References}

- Aazazi, SH (1997). Family Sociology. Tehran: Female Studies Press. (Persian)

- Daneshvar, A (1981). Child Psychology. Tabriz: University of Tabriz Press. (Persian)

- Efterkar Jahromi, G (2009). Human Rights, Environment and Sustainable Development in Environmental Law (Theories and Procedures). Tehran: Publishing House. (Persian)

- Ghafari Farsani, B (2008). "Looking at The worst Forms of Child Labor". Journal of Private Law Studies, 38 (2):25-38. (Persian)

- Hashemi, M (2001). Fundamental Rights and Political Structures. Tehran: Mizan Press. (Persian)

- Hashemi, M (2004). Human Rights and Fundamental Freedom. Tehran: Mizan Press. (Persian)

- Himonga, N \& Stuttaford, F.M (2014). "Social Ssolidarity and The Right to Health: Essential Elements for People-Centred Health Systems". Journal Health Policy and Planning, 14(1):18.

- Ibrahim Gol, A (2007). "The Right of Access to food in Conflicts in International Law". Journal of International Law, 25 (39): 221243. (Persian)

- Kamelnia, H (2008). Comparative Analysis and Research of the Collective Architecture Approach from the Perspective of Collective Psychology. PhD Thesis by Consultation of Qolamreza Eslami, Tehran: University of Tehran. (Persian)

- KeyNia, M (1994). Bases of Criminology (Social Factors of Divorce). Qom: Matbouat Dini Press. (Persian)
- Kiani, A \& Ismaeilzadeh Kovaki, A (2011). "Analyzing and Planning a Child Friendly City from Viewpoint of Children". Journal of Bagh Nazar, 9 (20): 51-63. (Persian)

- Lee, E (2013). "Education as a Human Rights in the $21^{\text {st }}$ Century". Journal of Democracy \& Education, 27(1): 1-9.

- Mahmoudi Janaki, F (2006). "Security \& Insecurity from Viewpoints of Criminal Policy". Legal Perspective Journal, 8(1): 168197. (Persian)

- McLeod, J (2014). A peaceful Pedagogy; Teaching Human Rights Across the Curriculm. Newcastle: The University of Newcastle, Publications Primary Teacher Education.

- MohammadZade Rahni, MR (2007). "Juridical Study on Sport Accidents". Journal of Jurisprudence and History of Civilization, 4(16): 91-125. (Persian)

- NaserZadeh, H (1993). Human Rights Declaration. Tehran: Majd Press. (Persian)

- Qasemi Roshan, I (2002). "The Ability of Family in Preventing Social Deviants". Journal of Female Studies, 17(1): 1-29. (Persian)

- Seyed Fatemi, MQ (2010). Human Rights in Contemporary World. Tehran: Shahr Danesh Press. (Persian)

- TalebZade, M (2005). The principles and Planning for Education and Training in PreSchool Stage. Tehran: Jahad Daneshgahi Press. (Persian) 